\title{
Scrotal Edema in Dilated Cardiomyopathy
}

\author{
Edema da Bolsa Escrotal em Cardiomiopatia Dilatada
}

Óscar FABREGAT-ANDRÉS ${ }^{1}$, Miriam CORET-MOYA², Francisco RIDOCCI-SORIANO ${ }^{1}$

Acta Med Port 2014 Jan-Feb;27(1):146-146

Keywords: Cardiomyopathy, Dilated; Edema; Scrotum.

Palavras-chave: Cardiomiopatia Dilatada; Edema; Escroto.

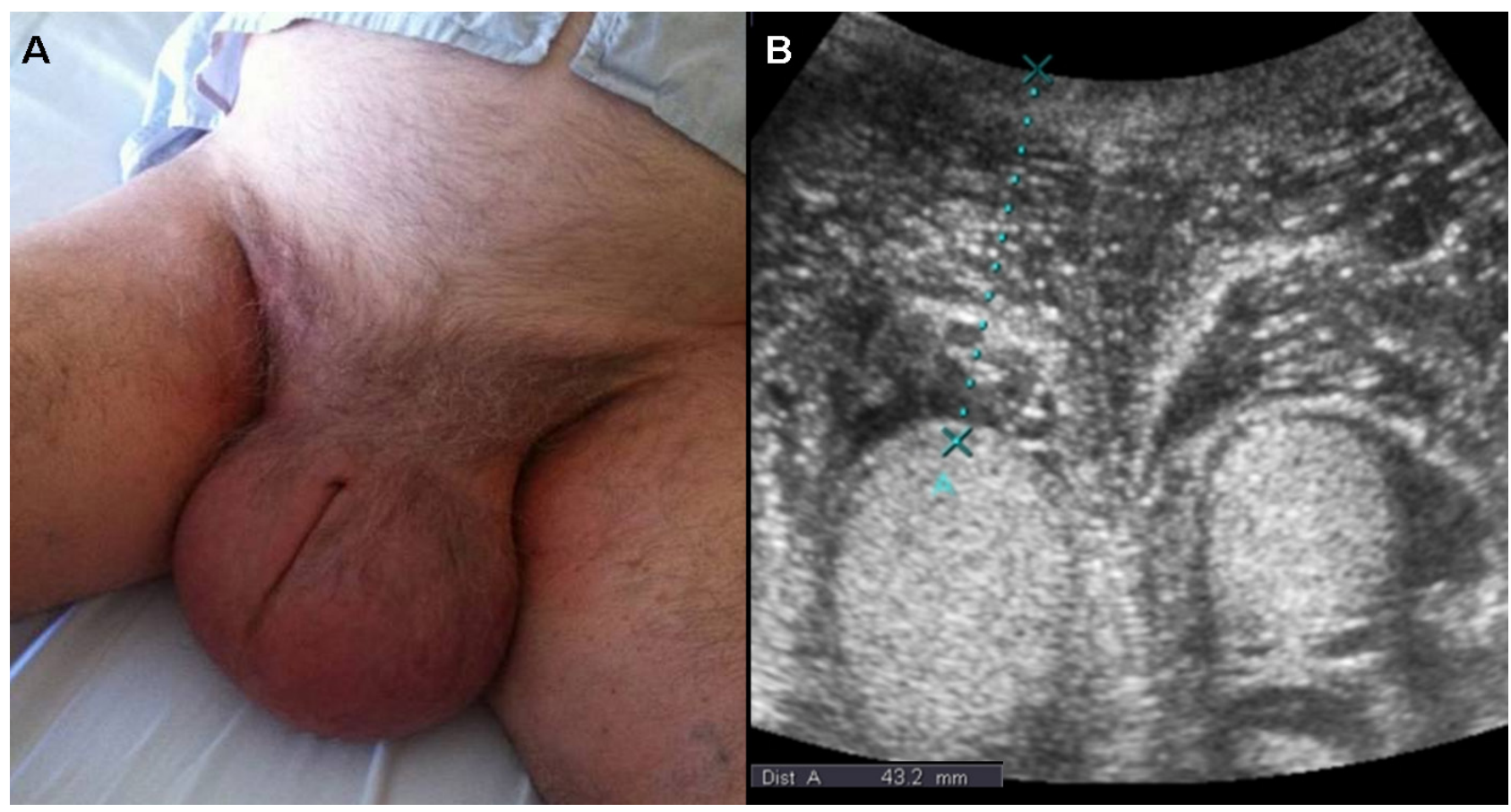

Figure $1 \mathrm{~A}$ - Picture of the scrotal edema showing the complete invaginationof the penis into the scrotum

Figure 1B - Testicular ultrasound showing a softtissue edema with skin thickness of $43 \mathrm{~mm}$

A 64-year-old male with a history of permanent atrial fibrillation and non-ischemic dilated cardiomyopathy was admitted to our centre with acute decompensated heart failure. He presented with progressive exertional dyspnea, orthopnea and leg swelling. Initial physical examination revealed arterial hypotension $(86 / 45 \mathrm{mmHg})$, irregular heartbeat with a mitral 2/6 systolic murmur and minimal peripheral edema. Subsequent more careful examination showed a giant scrotal edema with intussusception of the penis into the scrotum (Fig. 1A). As recommended, ${ }^{1}$ a testicular ultrasound was performed showing morphologically normal tes- tis and appropriately vascularized, and soft tissue edema with skin thickness of $43 \mathrm{~mm}$ (Fig. 1B). After a week of intravenous diuretic therapy, the patient lost $12 \mathrm{~kg}$ in weight and the scrotal edema was resolved almost entirely.

Congestive heart failure was usually associated with fluid build-up in abdomen and peripheral regions. The occurrence of a mild scrotal edema is a common finding in this clinical setting. ${ }^{2}$ The clinical presentation of this case is striking because edema was focused in the scrotum, with minimal swelling in lower limbs and abdominal region.

\section{REFERENCES}

1. Anastasi G, Buemi M, Mucciardi G, Crea G, Sanfilippo G, Magno C. Usefulness of ultrasonography in the diagnosis of acute scrotal edema. Arch Ital Urol Androl. 2000;72:238-40

2. McMurray JJ, Adamopoulos S, Anker SD, Auricchio A, Böhm M, Dickstein K, et al. ESC guidelines for the diagnosis and treatment of acute and chronic heart failure 2012: The Task Force for the Diagnosis and Treatment of Acute and Chronic Heart Failure 2012 of the European Society of Cardiology. Eur Heart J. 2012;33:1787-847. 


\section{Scrotal Edema in Dilated Cardiomyopathy \\ Acta Med Port 2014:27:146-146}

Publicado pela Acta Médica Portuguesa, a Revista Científica da Ordem dos Médicos

Av. Almirante Gago Coutinho, 151

1749-084 Lisboa, Portugal.

Tel: +351218428 215

E-mail: submissao@actamedicaportuguesa.com

www.actamedicaportuguesa.com

ISSN:0870-399X | e-ISSN: 1646-0758

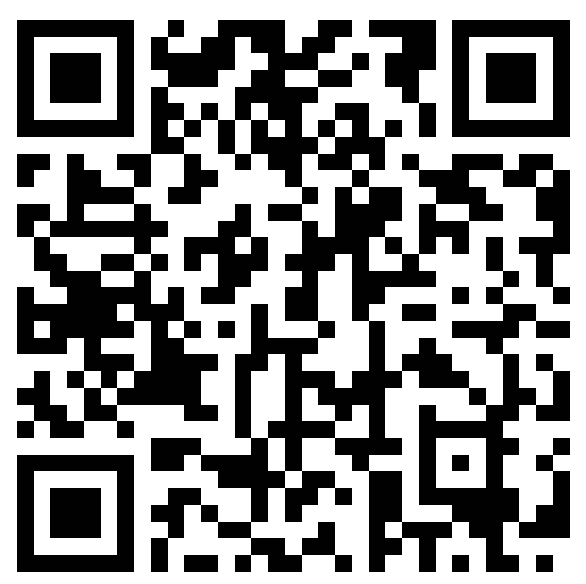

